\title{
Pendred Syndrome in a Large Consanguineous Brazilian Family Caused by a Homozygous Mutation in the SLC26A4 Gene
}

clinical case report

\author{
Adriana Lofrano-Porto \\ GustaVo B. BARRA \\ Paula P. Nascimento \\ PatrícIa G. G. Costa \\ ÉRICA C. GARCIA \\ RODRIGO F. VAZ \\ ANA R. T. BATISTA \\ ANA C. R. DE FREITAS \\ BRUNO L. B. CherULII \\ FAYEZ BAHMAD JR. \\ LARISSA G. FIGUEIREDO \\ FRANCISCO A. R. NeVES \\ Luiz Augusto CasularI
}

Section of Endocrinology, Faculty of Medicine, University Hospital of Brasilia, University of Brasilia (ALP, PPN, ECG, RFV, ARTB, LAC); Sabin Institute and Laboratory of Clinical Analysis (GBB, PGGC); Radiology Center, University Hospital of Brasilia (ACRF, BLBC);

Department of Otolaryngology, Head \& Neck Surgery, Brasilia University School of Medicine (FBJ), Brasilia, DF, Brazil; Section of Endocrinology, Faculty of Medicine, Amazon State University, Manaus, AM, Brazil (LGF); Molecular Pharmacology Laboratory, Faculty of Health Sciences, University of Brasilia (FARN), Brasilia, DF, Brazil.

Received in 26/8/2008 Accepted in 14/10/2008
ABSTRACT

Pendred Syndrome (PS) is an autossomal recessive disorder characterized by sensorineural deafness, goiter and iodide organification defect. The hearing loss is associated with inner ear abnormalities, ranging from an isolated enlarged vestibular aqueduct (EVA) to a typical coclear dysplasia. Mutations in the gene that encodes pendrin (SLC26A4), a chloride/iodide transporter, have been shown to be associated with PS. We describe the clinical and molecular characteristics of a large consanguineous family harboring a mutation in the SLC26A4 gene. The proband was a 26-year-old deaf Brazilian woman who presented a bulky multinodular goiter and hypothyroidism since puberty. Five other siblings were deaf: one brother had a similar phenotype, three siblings also had goiters but normal thyroid function tests, and one brother had only a subtle thyroid enlargement. Other 4 siblings had no thyroid or hearing disorder. Parents were first degree cousins and had normal hearing. The mother was healthy, except for subclinical hypothyroidism; the father was deceased. A perchlorate test in the proband showed a discharge of $21 \%$ of the incorporated iodide $2 \mathrm{~h}$ after the administration of $1 \mathrm{~g}$ of $\mathrm{KClO} 4$. Audiological examinations showed profound hearing loss in all deaf subjects; CT and MRI of the temporal bones showed EVA in all of them. Genomic DNA was isolated from whole blood, from the 6 affected and 4 unaffected siblings, the mother and control. The coding region of the PDS gene (exons 2-21), including exon/intron boundaries, were amplified by PCR and sequenced. A single base-pair (T) deletion at position 1197 of exon 10 was detected in homozygous state in the 6 deaf siblings. The mother and 2 unaffected siblings were heterozygous for this mutation, which has been described by Everett et al. The 1197delT mutation is predicted to result in a frameshift and a truncated protein. The existence of PS phenocopies and intrafamilial phenotypic variability are well documented. The definite diagnosis requires molecular analysis. Our study illustrates the value and challenges of mutational analysis in selected patients with PS. (Arq Bras Endocrinol Metab 2008; 52/8:1296-1303)

Keywords: Pendrin; Sensorineural deafness; Goiter

\section{RESUMO}

\section{Síndrome de Pendred Causada por Mutação em Homozigoze no Gene SLC26A4 em uma Família Brasileira Consangüínea.}

A syndrome de Pendred (SP) é uma doença autossômica recessiva caracterizada por surdez neurossensorial, bócio e defeito de organificação do iodo. A perda auditiva está associada a anormalidades do ouvido interno, desde a dilatação isolada do aqueduto vestibular (DAV) até uma típica displasia coclear. Mutações no gene que codifica a pendrina (SLC26A4), um transportador de cloreto/iodeto, têm sido associadas à SP. Descrevemos as características clínicas e moleculares de uma grande família consangüínea portadora de uma mutação no gene SLC26A4. O caso-índice era uma paciente do sexo feminino, brasileira, 26 anos, portadora de surdez congênita, que apresentava um volumoso bócio multinodular e hipotireoidismo desde a 
puberdade. Outros cinco irmãos eram surdos: um irmão tinha fenotipo semelhante, três também tinham bócio, porém com função tiroideana normal e um irmão tinha apenas um discreto aumento da tiróide. Outros quatro irmãos não apresentavam alteração tiroideana ou auditiva. Os pais eram primos de primeiro grau e tinham audição normal. A mãe era saudável, exceto por hipotireoidismo subclínico; o pai era falecido. O teste do perclorato no caso-índice revelou a liberação de $21 \%$ do iodo incorporado duas horas após a administração de $1 \mathrm{~g}$ de $\mathrm{KClO} 4$. Os exames audiológicos mostraram perda auditiva profunda em todos os indivíduos afetados; TC e RMN dos ossos temporais mostraram DAV em todos eles. O DNA genômico foi isolado do sangue total dos seis irmãos afetados e dos quatro não-afetados, da mãe e do controle. A região codificante do gene PDS (éxons 2-21), incluindo as junções éxon/íntron, foram amplificadas por PCR e seqüenciadas. Foi detectada a deleção de uma base (T) na posição 1197 do éxon 10, em homozigoze, nos seis irmãos afetados. A mãe e dois irmãos não-afetados eram heterozigotos para a mutação, que foi descrita inicialmente por Everett e cols. A mutação 1197delT provavelmente resulta em um erro de fase de leitura (frameshift) e em uma proteína truncada. A existência de fenocópias da SP e a variabilidade fenotípica intrafamiliar são bem conhecidas. O diagnóstico definitivo requer análise molecular. O presente estudo ilustra o valor e os desafios da análise mutacional em pacientes selecionados com SP. (Arq Bras Endocrinol Metab 2008; 52/8:1296-1303)

Descritores: Pendrina; Surdez neurossensorial; Bócio

\section{INTRODUCTION}

endred syndrome (PS) is an autosomal recessive disorder characterized by bilateral sensorineural deafness, goiter and iodide organification defect, with an estimated incidence of 7.5 to 10 in 100,000 individuals (1). This disorder may account to approximately $10 \%$ of the cases of hereditary deafness, making it the most common cause of syndromic deafness (1). Despite the defect in iodide organification, which can be demonstrated by a positive perchlorate discharge test, thyroid function is highly variable and hypothyroidism is described in approximately half of the cases (2). The hearing loss is associated with inner ear abnormalities, which can be readily identified with appropriate imaging procedures, ranging from an isolated enlarged vestibular aqueduct (EVA) to a typical cochlear malformation known as Mondini dysplasia. This condition is characterized by hypoplastic upper turns of the cochlea originating a common dysfunctional cavity $(3,4)$.

The gene involved in this syndrome is located at chromosome 7 and encodes a protein pertaining to the solute carrier family 26, member 4 (SLC26A4), a 780 amino acid protein that functions as a chloride, iodide and/or bicarbonate transporter, also known as pendrin (5). To date, more than 100 mutations spanning the whole coding region of the SLC26A4 gene have been shown to be associated with PS, although the genotype-phenotype correlations are still poor and remain unexplained. Mutations in the SLC26A4 cause not only classical PS but also an autosomal recessive form of isolated deafness without thyroid disease, both associated with EVA $(6,7)$.

In this study, we report the clinical and molecular characteristics of a large consanguineous Brazilian family harboring a mutation in the SLC26A4 gene, from which six affected siblings presented with subtle phenotypic variations. Furthermore, we review recent data from studies that have contributed to the understanding of the physiopathological roles of pendrin in humans.

\section{SUBJECTS AND METHODS}

\section{Case reports}

The proband (subject IV-4, Figure 1), a deaf Brazilian woman, presented at the age of 26 complaining of a bulky multinodular goiter. She noted progressive thyroid growth since the age of 9 , and has been diagnosed with hypothyroidism at 12, when levothyroxine was started. Except for congenital deafness, she had normal cognitive and neural development. She had four normal pregnancies and vaginal labors; the second was a twin pregnancy that resulted in a stillborn of unknown cause and a healthy newborn. Her husband was a non-consanguineous deaf man (not examined) and all 


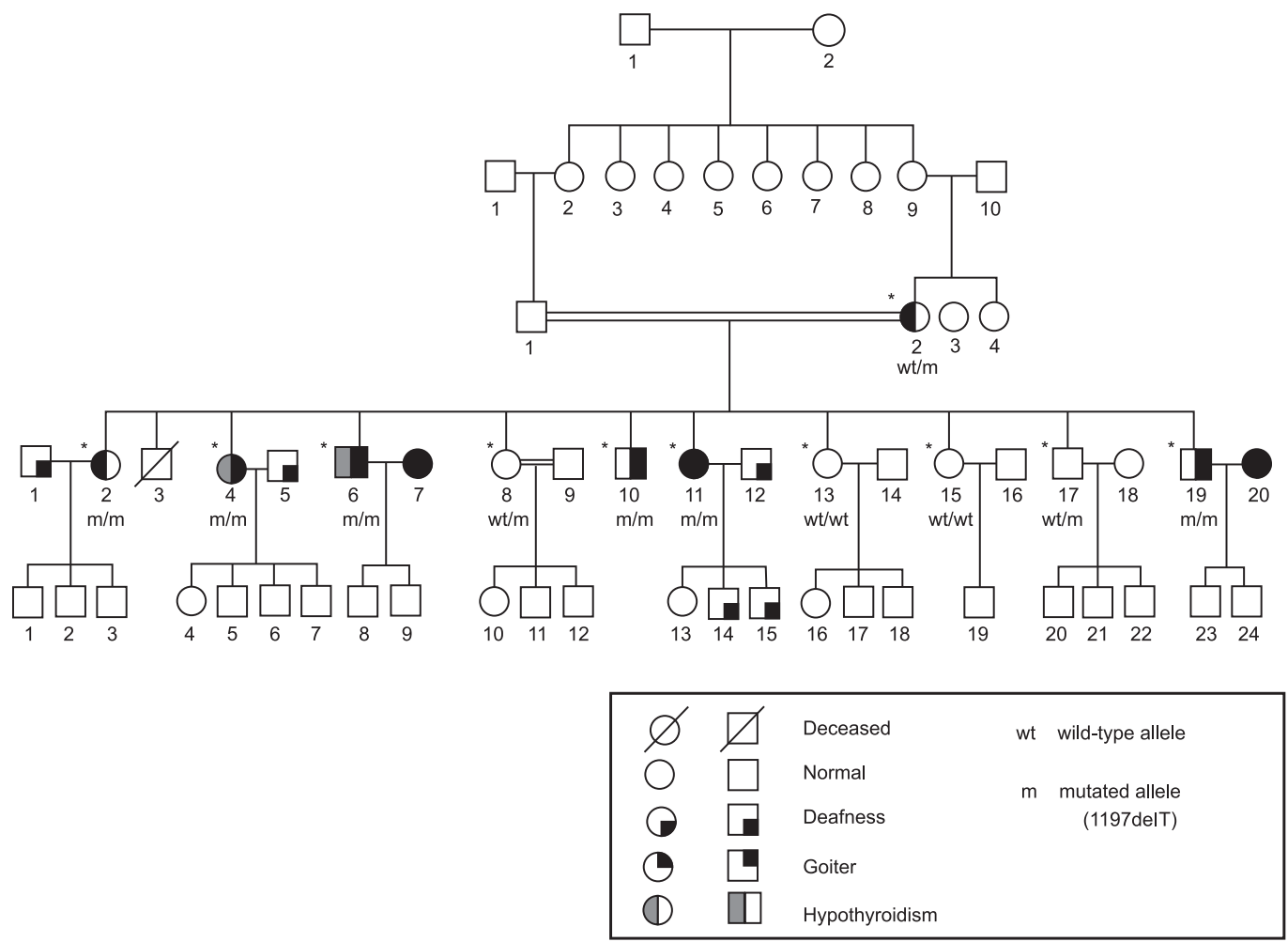

Figure 1. Pedigree of the family with Pendred syndrome caused by a 1197delT in the SLC26A4 gene. The subjects evaluated in this study are shown $\left(\left(^{*}\right)\right)$.

four living children were healthy and had normal hearing. On physical examination, her height was $160 \mathrm{~cm}$ and weight was $63.6 \mathrm{~kg}$. Blood pressure was normal $(112 \times 70 \mathrm{mmHg})$. A large multinodular goiter with predominance of the right lobe was noted, with no other physical abnormality. Because of progressive thyroid enlargement and compressive symptoms, she underwent a total thyroidectomy at the age of 46 .

Family history was remarkable for congenital deafness and goiter. The proband was the third of 11 siblings. Five other siblings were deaf; among them, two brothers (IV-6 and IV-10) and two sisters (IV-2 and IV-11) also had a history of thyroid enlargement since early puberty that progressively evolved to large multinodular goiters, whereas one brother (IV-19) had only a modest diffuse thyroid enlargement.

Other four siblings had no thyroid or hearing disorder (IV-8, IV-13, IV-15 and IV-17). Parents were first degree cousins and had normal hearing. The mother (III-2) was healthy, except for subclinical hypothyroidism, with negative thyroid auto-antibodies tests. The father (III-1) was deceased. Family's pedigree is shown in Figure 1.

\section{Clinical studies}

All patients provided written informed consent to participate in this study, which was approved by the Research Ethics Committee of Faculty of Medicine, University of Brasília, Brazil.

In order to confirm the clinical suspicion of PS, a perchlorate test was performed in the proband. Two hours after administration of 131-iodine $(50 \mathrm{mCi}), \mathrm{lg}$ of perchlorate $(\mathrm{KClO} 4)$ was administered, and 2 hours later, the discharge of iodide was determined. A discharge of less than $10 \%$ of the incorporated iodide is expected in normal individuals $(2,8)$.

Evaluation of the thyroid function was based on serum determinations of thyroid-stimulating hormone (TSH), free thyroxine (FT4) and total triiodotyronine (T3) levels, using a chemiluminescent immunoassay (IMMULITE 2000, DPC).

Thyroid ultrasonography (US) was performed in five of the six deaf siblings and the mother, by the same observer, using the sonography equipment EnVisor Ultrasound System (PHILLIPS). Audiological examination included tympanometry, speech recognition 
threshold (SRT), pure-tone audiometry (PTA) and transiently evoked otoacoustic emissions (OAE). Imaging studies from the inner ear were obtained with the use of computed tomography (CT) and magnetic resonance imaging (MRI) of the temporal bones. EVA was defined when enlargement of the vestibular aqueduct was $>1.5 \mathrm{~mm}$ at midway between the endolymphatic sac and the vestibule (9-11).

\section{Molecular studies}

Genomic DNA samples from ten siblings (6 affected and 4 unaffected), their mother and a control were prepared from $50 \mu \mathrm{L}$ whole blood by the Chelex-100 method (12). The coding region (exons 2 to 21 ) of the SLC26A4 gene, including exon/intron boundaries, was amplified by PCR with primers designed for this study (Table 1), with the exception of exon 3 primers,

Table 1. Primers used in the SLC26A4 gene amplification.

\begin{tabular}{|c|c|c|c|}
\hline PRIMER NAME & EXON & SEQUENCES 5' and 3' & PRODUCT SIZE (pb) \\
\hline $\begin{array}{l}\text { SLC26A4 2F } \\
\text { SLC26A4 2R }\end{array}$ & 2 & $\begin{array}{l}\text { GGCTGCAGCTAACAGGTGATC } \\
\text { GAGGACCGGAGACCGAAAGTC }\end{array}$ & 432 \\
\hline $\begin{array}{l}\text { SLC26A4 3F } \\
\text { SLC26A4 3R }\end{array}$ & 3 & $\begin{array}{l}\text { ACAGTTCTTGGCAAAAGCATGG } \\
\text { GAAGGGTAAGCAACCATCTGTCAC }\end{array}$ & 411 \\
\hline $\begin{array}{l}\text { SLC26A4 4F } \\
\text { SLC26A4 4R }\end{array}$ & 4 & $\begin{array}{l}\text { TTTGCATCATCATAAAGGCAAAGTC } \\
\text { TGAAATCCCATTTCCCTGACAA }\end{array}$ & 419 \\
\hline $\begin{array}{l}\text { SLC26A4 5F } \\
\text { SLC26A4 5R }\end{array}$ & 5 & $\begin{array}{l}\text { CTCAGCTTCTTCGTGAACAAAC } \\
\text { TTTGGGTCCAGGAAATTACTTTGT }\end{array}$ & 439 \\
\hline $\begin{array}{l}\text { SLC26A4 6F } \\
\text { SLC26A4 6R }\end{array}$ & 6 & $\begin{array}{l}\text { GTGCTATAGGCAGGCTACTAGTGTT } \\
\text { CCTGGCCCAGACTCAGAGAAT }\end{array}$ & 364 \\
\hline $\begin{array}{l}\text { SLC26A4 7/8F } \\
\text { SLC26A4 7/8R }\end{array}$ & 7 and 8 & $\begin{array}{l}\text { TGGGAAGATTCATATGAGAATTGATTG } \\
\text { TGGTTGTTCTTCCAGATCACA }\end{array}$ & 581 \\
\hline $\begin{array}{l}\text { SLC26A4 9F } \\
\text { SLC26A4 9R }\end{array}$ & 9 & $\begin{array}{l}\text { CATGTGAAATGGCATGGATGG } \\
\text { GGTCTGGTGAAAGAATCCAACC }\end{array}$ & 583 \\
\hline $\begin{array}{l}\text { SLC26A4 10F } \\
\text { SLC26A4 10R }\end{array}$ & 10 & $\begin{array}{l}\text { CGCAGAGTAGGCATGGGAGTTT } \\
\text { TTGTCCTGCTAAGCTCGGTGC }\end{array}$ & 314 \\
\hline $\begin{array}{l}\text { SLC26A4 11/12F } \\
\text { SLC26A4 11/12R }\end{array}$ & 11 and 12 & $\begin{array}{l}\text { AGACAGGGAAGTATGAAGTGTG } \\
\text { TTTCTCCTCTGGAGTTCCCAAA }\end{array}$ & 555 \\
\hline $\begin{array}{l}\text { SLC26A4 13F } \\
\text { SLC26A4 13R }\end{array}$ & 13 & $\begin{array}{l}\text { AGGTAGTTATCACATGATGGTACCTG } \\
\text { GAGCACAGCAGTAGAGGACAT }\end{array}$ & 501 \\
\hline $\begin{array}{l}\text { SLC26A4 14F } \\
\text { SLC26A4 14R }\end{array}$ & 14 & $\begin{array}{l}\text { AAACACCAGAATGATGGGCTC } \\
\text { GTCAGAAGGTGCACTGGATC }\end{array}$ & 338 \\
\hline $\begin{array}{l}\text { SLC26A4 15F } \\
\text { SLC26A4 15R }\end{array}$ & 15 & $\begin{array}{l}\text { CTACCCAGCTCСTCTGACAA } \\
\text { GCCCTACACAAAGGGAAGAGGG }\end{array}$ & 329 \\
\hline $\begin{array}{l}\text { SLC26A4 16F } \\
\text { SLC26A4 16R }\end{array}$ & 16 & $\begin{array}{l}\text { ACCCITGAGAAATAGCCTTCCAG } \\
\text { CCACTCCCGCTTGCCTATAA }\end{array}$ & 357 \\
\hline $\begin{array}{l}\text { SLC26A4 17F } \\
\text { SLC26A4 17R }\end{array}$ & 17 & $\begin{array}{l}\text { AGTTTGGGCTGAGGTGAAACC } \\
\text { CAAAGCCCATGTATTGCCCTG }\end{array}$ & 486 \\
\hline $\begin{array}{l}\text { SLC26A4 18F } \\
\text { SLC26A4 18R }\end{array}$ & 18 & $\begin{array}{l}\text { CGCTGGATGTTGCCTCTCT } \\
\text { GGCCTTCAGACATAATGTGCCA }\end{array}$ & 357 \\
\hline $\begin{array}{l}\text { SLC26A4 19F } \\
\text { SLC26A4 19R }\end{array}$ & 19 & $\begin{array}{l}\text { TTTCTTAGCTGGGCATGGTAGG } \\
\text { GGAATTIATGTACACAAATCCCAGATCAC }\end{array}$ & 705 \\
\hline $\begin{array}{l}\text { SLC26A4 2OF } \\
\text { SLC26A4 2OR }\end{array}$ & 20 & $\begin{array}{l}\text { AGAAGCACCAGGAAAGCTTCA } \\
\text { GGGAATTATGTTCCCTGACAGTTC }\end{array}$ & 283 \\
\hline $\begin{array}{l}\text { SLC26A4 21F } \\
\text { SLC26A4 21R }\end{array}$ & 21 & $\begin{array}{l}\text { CCTAAGATGAGTAGCAGTAAGCA } \\
\text { GCTGCCAAATCGTCTGAATAATTC }\end{array}$ & 354 \\
\hline
\end{tabular}


which were described previously (1). Amplification was performed on a PTC-100 thermal cycler (MJ Research, Inc) using the following cycling conditions : initial denaturation for 3 minutes at $94{ }^{\circ} \mathrm{C}$; followed by $34 \mathrm{cy}$ cles of $1 \mathrm{~min}$ at $94{ }^{\circ} \mathrm{C}, 1 \mathrm{~min}$ at $55^{\circ} \mathrm{C}$, and $\mathrm{l}$ min at 72 ${ }^{\circ} \mathrm{C}$; and final extension for $5 \mathrm{~min}$ at $72{ }^{\circ} \mathrm{C}$. The PCR products were analyzed by electrophoresis on $1.5 \%$ Tris-acetate-EDTA/ethidium bromide agarose gels under ultraviolet illumination and were later sequenced in both sense and antisense orientations, with the use of an automated sequencer ABI-377 (Perkin-Elmer Corp., Foster City, CA). The sequences were compared to the NCBI Homo sapiens SLC26A4 DNA sequence reference assembly (ACCESSION NC_000007 REGION: 107088316-107145490).

\section{RESULTS}

\section{Clinical characterization of the six siblings with PS}

The perchlorate test showed a discharge of $21 \%$ of the incorporated iodide in the proband, a finding consis- tent with the defect in iodide organification into thyroglobulin.

The clinical and radiologic evaluation of the affected siblings and their mother are summarized in table 2 . In the proband, thyroid ultrasonography showed a multinodular, heterogeneous goiter, with a lobular contour and small cystic areas with sparse calcifications. Histopathological examination of the proband's thyroid specimen revealed a large colloid goiter, weighing 310 $\mathrm{g}$, with small areas of follicular hyperplasia, fibrosis and calcifications.

The ultrasonographic thyroid appearance was similar in all affected siblings, except in one brother who had only a discrete thyroid enlargement, with no other abnormality (IV-19). Subjects IV-6 and IV-10 had undergone partial thyroidectomy and were taking levothyroxine at the time of the evaluation for this study. Altogether, five deaf siblings had palpable bulky multinodular goiters (IV-2, IV-4, IV-6, IV-10, IV-11) and one (IV-19) had a slightly increased homogeneous thyroid gland, detected on ultrasonography. On the other hand, thyroid function was variably disturbed in these subjects (Table 2). Only two (IV-4 and IV-6) de-

Table 2. Clinical and radiological aspects of six siblings with Pendred syndrome due to the 1197delT mutation in the SLC26A4 gene.

\begin{tabular}{|c|c|c|c|c|c|c|c|c|}
\hline \multirow[t]{2}{*}{$\begin{array}{c}\text { Subjetct } \\
\text { No. }\end{array}$} & \multirow[t]{2}{*}{ Sex } & \multirow{2}{*}{$\begin{array}{l}\text { Age } \\
\text { (years) }\end{array}$} & \multicolumn{2}{|c|}{ Endolymphatic Sac } & \multicolumn{2}{|c|}{$\begin{array}{l}\text { Vestibular Aqueduct } \\
(\mathrm{NI}<1,5 \mathrm{~mm})\end{array}$} & \multirow{2}{*}{$\begin{array}{c}\text { Goiter } \\
\left(\text { volumes- } \mathrm{cm}^{3}\right)\end{array}$} & \multirow[t]{2}{*}{ Thyroid function } \\
\hline & & & $\mathbf{R}$ & $\mathbf{L}$ & $\mathbf{R}$ & $\mathbf{L}$ & & \\
\hline IV-2 & $\mathrm{F}$ & 51 & normal & enlarged & 2,9 & 3,5 & $\begin{array}{c}\text { multinodular } \\
44,2\end{array}$ & normal \\
\hline IV-4 & $\mathrm{F}$ & 47 & enlarged & enlarged & 3,2 & 3,5 & $\begin{array}{c}\text { multinodular } \\
186,3^{*}\end{array}$ & hypothyroidism** \\
\hline IV-6 & M & 45 & normal & enlarged & 1,1 & 1,8 & $\begin{array}{l}\text { multinodular } \\
114,2^{*}\end{array}$ & hypothyroidism \\
\hline IV-10 & M & 41 & normal & normal & 1,8 & 2,7 & $\begin{array}{l}\text { multinodular } \\
\qquad 18,4^{*}\end{array}$ & Normal \\
\hline IV-11 & $\mathrm{F}$ & 38 & enlarged & enlarged & 3,6 & 3,1 & $\begin{array}{l}\text { multinodular** } \\
\text { ND }\end{array}$ & Normal \\
\hline IV-19 & M & 29 & enlarged & enlarged & 2,3 & 2,7 & $\begin{array}{c}\text { subtle } \\
\text { enlargement } \\
27,3\end{array}$ & Normal \\
\hline
\end{tabular}

R: right; L: left; NI: normal; F: female; M: male; ND: not determined; § thyroid volume determined by ultrasonography; \# in subjest V-4, tyroid volume was determined before total thyroidectomy was perfomed; \#\# subject IV-4 developed hypothyroidism with positive anti-thyroglobulin antibodies, many years before thyroidectomy: * thyroid remanscent size after parcial thyroidectomy; ** thyroid ultrasonogram could not be obtained from subject IV-1 1, but physical examination reveale

a multinodular goiter. 
veloped hypothyroidism before thyroidectomy was performed, leading to the need for levothyroxine replacement treatment. This condition was associated with the presence of thyroid auto-antibodies in one of them (IV-4).

Audiological examination showed bilateral profound hearing loss (PTA $>90 \mathrm{~dB}$ ) in all six affected siblings. Computed tomography (CT) and magnetic resonance imaging (MRI) of the temporal bones showed variably enlarged vestibular aqueducts (EVA) and uni- or bilaterally dilated endolymphatic sacs in all of them (Table 2 and Figure 2).


Figure 2. Axial volumetric hybrid MRI sequence with T2WI predominance (FIESTA). Bilateral vestibular aqueductal enlargement (a) and endolymphatic sac dilatation (b) are shown by arrows.

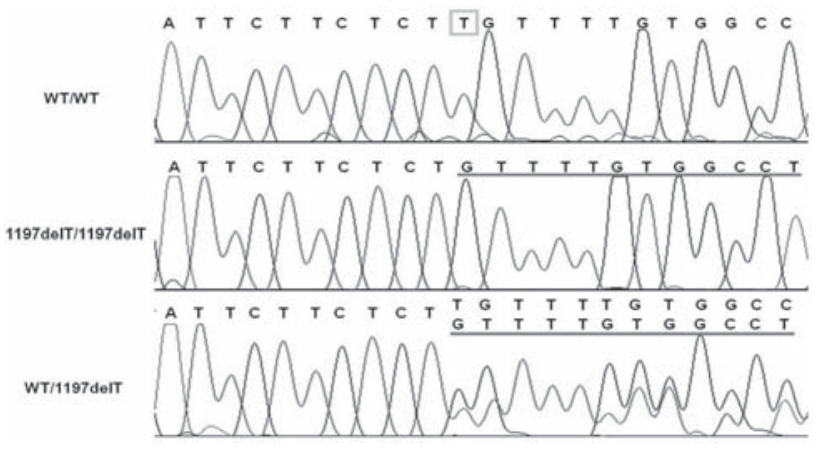

Figure 3. Eletropherograms of wild-type, 1197delT homozygote and heterozygote, showing the deleted $T$ residue (square) and the resultant frameshift (underlined) in the mutant allele.

\section{MOLECULAR ANALYSIS}

A single nucleotide $(\mathrm{T})$ deletion at position 1197 of exon 10 (1197delT) was detected in homozygous state in the six deaf siblings (Figure 3). The 1197delT mutation, also named FS400, is predicted to result in a frameshift from codon 400 leading to a premature stop at codon 430 (Figure 4). The mother, one brother and one sister were heterozygous for the mutation.

\section{DISCUSSION}

We report a Brazilian consanguineous family, in which six subjects harbor a homozygous mutation in the SLC26A4 gene (1197delT), causing Pendred syndrome. The clinically unaffected mother and two other siblings are heterozygous for this mutation, which has been first described in 1997 by Everett and cols. (1), in three families of Arabic descent. Since then, at least eight families harboring this mutation have been identified (13-16). The deletion of a $\mathrm{T}$ residue results in a frameshift and an altered amino acid sequence from $\mathrm{co}^{-}$

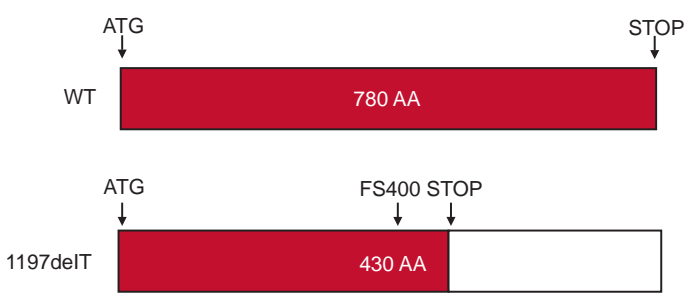

Figura 4. Schematic representation of the predicted frameshift from codon 400 , leading to a premature stop at codon 430 , as a consequence of the 1197delT mutation, also named FS400. 
don 400 (Figure 4), leading to a premature stop codon at position 430 , which predicts a truncated protein. The mutation 1197delT is located in the seventh transmembrane domain of the mature protein and results in the loss of the last two and a half transmembrane domains with the whole carboxi-terminal portion, impairing its biological activity (7).

Although clinical information about the affected subjects from previous families harboring the $1197 \mathrm{delT}$ mutation is scanty, some variability on the thyroid phenotype was noted. Similar to our findings, the majority of patients harboring this mutation in homozygous state had goiters, with or without hypothyroidism, except two subjects in a family from Lebanon (13-16). In a previous study of other large kindred from Brazil, Kopp and cols. identified a deletion of a $\mathrm{T}$ residue at position 249 of exon 3 of the SLC26A4 gene associated with PS. However, differently from the present study, Kopp and cols. found intrafamilial phenotype-genotype variability, suggesting that the clinical diagnosis of PS may be confounded by the presence of similar phenotypes caused by distinct environmental or genetic factors (17).

In the thyroid, the main function of pendrin is to regulate the efflux of iodide at the apical membrane of the thyrocytes, where it acts as an iodide-chloride transporter. Specifically, it is presumed to play a significant role on the transport of iodide into the follicular lumen, where it is coupled to thyroglobulin. If pendrin activity is impaired, as in PS, cytoplasmatic iodide accumulation occurs. However, in the majority of the cases, the defect is incomplete and most patients have a preserved thyroid function or only subclinical or mild hypothyroidism $(18,19)$.

In the present study, a positive perchlorate test in the proband confirmed the iodide organification defect. However, although a similar iodide organification status would be expected in all affected members, thyroid function and growth were variably compromised. Only two affected subjects developed hypothyroidism prior to thyroidectomy, and the total volume of the thyroid determined by US varied from $27.3 \mathrm{~cm}^{3}$ to $186.3 \mathrm{~cm}^{3}$. These findings are in accordance with previous studies, demonstrating significant intrafamilial phenotypic variability (15).

The mechanisms involved in goiter formation in PS are not completely understood, but may include transient increases in serum TSH in response to low thyroid hormone synthesis and increased iodide retention in thyrocytes. Environmental factors, such as nutritional iodide intake, also appear to act as important modifiers of the thyroid phenotype. Recent in vitro studies using thyrocytes from PS patients and normal individuals have shown that some iodide can leave PS thyrocytes, although less efficiently than normal cells (20). The absence of goiter observed in some PS patients keeps up with these observations. Moreover, Palos and cols. demonstrated some evidence of the existence of adaptive mechanisms associated with impaired organification, that could work together in order to avoid hypothyroidism, such as increased deiodinase activities in goiters of PS patients and the resulting increased intrathyroidal conversion of $\mathrm{T} 4$ into $\mathrm{T} 3$.

The audiological phenotype typically seen in PS is that of a profound hearing loss, with prelingual onset and a progressively worsening course $(3,6,21,22)$. Our findings in the six homozygote patients corroborate these observations. The reasons for the characteristic hearing phenotype are probably related to the functions of pendrin in the inner ear, where it is presumed to participate in the formation and resorption of the endolymph. It has been shown that defects in chloride transport may lead to toxic and osmotic injury to the neuroepithelium, resulting in the progressive sensorineural hearing loss observed in PS patients (23). The enlargement of the endolymphatic duct (ED) and sac (ES), as well as dilation of the surrounding structures (ventricular aqueduct and cochlea), is believed to be related to the increased osmotic pressure and volume of the endolymph, and is frequently seen in PS patients (3).

The functions of pendrin in the kidneys are less well understood. Previous studies have shown a role in mediating bicarbonate secretion and in the regulation of acid-base transport in the renal collecting duct (24). However, in PS patients, no acid-base disturbances have been noted, under physiological conditions. Recently, much research have focused on the potential relations of pendrin with blood pressure regulation. It has been suggested that pendrin-mediated chloride absorption in the distal nephron may be an important mechanism, by which aldosterone and angiotensin II modulate the renal regulation of blood pressure. Indeed, many studies have pointed to the role of pendrin as an important mediator of aldosterone actions in the kidneys (25). In light of these recent findings, additional studies are needed to clarify the renal impact of pendrin inactivation in humans.

In conclusion, our study illustrates the value of performing mutational analysis in selected patients, when the association of congenital deafness with goiter yields 
to the clinical diagnosis of PS. However, many conditions causing congenital hypothyroidism may mimic PS, particularly in infants. Although a positive perchlorate test indicates thyroid dishormonogenesis, it is not helpful to indicate the exact nature of the molecular defect. Due to the high predictive value of the detection of enlarged ED and ES in PS patients, appropriate imaging studies with high resolution CT and MRI are thus mandatory to the clinical diagnosis of PS, and must be performed before genetic analysis. The definite diagnosis requires molecular analysis.

Acknowledgements: We are thankful for the Sabin Institute and Laboratory of Clinical Analysis, Brasília, Brazil, for gently providing support for the molecular studies. The authors report having no conflicts of interest relevant to this article.

\section{REFERENCES}

1. Everett L, Glaser B, Beck JC, Idol JR, Buchs A, Heyman M, et al. Pendred syndrome is caused by mutations in a putative sulphate transporter gene (PDS). Nat Genet. 1997;17:411-22.

2. Reardon W, Coffey R, Chowdhury T, Grossman A, Jan H, Britton $K$, et al. Prevalence, age of onset and natural history of thyroid disease in Pendred syndrome. J Med Genet. 1999;36: 595-8.

3. Cremers C, Bolder C, Admiraal RJ, Everett LA, Joosten F, Van Hauwe $P$, et al. Progressive sensorineural hearing loss and a widened vestibular aqueduct in Pendred syndrome. Arch Otolaryngol Head Neck Surg. 1998;124:501-5.

4. Propst EJ, Stockley TL, Harrison RV, Gordon KA, Papsin BC. Temporal bone imaging in GJB2 deafness. Laryngoscope. 2006;116(12):2178-86.

5. Everett LA, Green E. A family of mammalian anion transporters and their involvement in human genetic diseases. Hum Mol Genet. 1999;8(10):1883-91.

6. Yang JJ, Tsai CC, Hsu HM, Shiao JY, Su CC, Li SY. Hearing loss associated with enlarged vestibular aqueduct and Mondini dysplasia is caused by splice-site mutation in the PDS gene. Hear Res. 2005;199:22-30.

7. Azaiez H, Yang T, Prasad S, Sorensen JL, Nishimura CJ, Kimberling WJ, et al. Genotype-phenotype correlations for $S L$ C26A4- related deafness. Hum Genet. 2007;122(5):451-7.

8. Wolff J. Perchlorate and the thyroid gland. Pharmacol Rev. 1998;50:89-102.

9. Lowe L, Vézina L. Sensorineural hearing loss in children. Radiographics. 1997;17:1079-93.

10. Goldfeld M, Glaser B, Nassir E, Gomori JM, Hazani E, Bishara N. CT of the ear in Pendred syndrome. Radiology. 2005;235(2): 537-40.

11. Vijayasekaran S, Halsted MJ, Boston M. When is the vestibular aqueduct enlarged? A statistical analysis of the normative distribution of vestibular aqueduct size. Am J Neuroradiol. 2007; 28:1133-8.

12. Walsh P. Chelex 100 as a medium for simple extraction of DNA for PCR-based typing from forensic material. Biotechniques. 1991;10:506-13.
13. Van Hauwe P, Everett LA, Coucke P, Scott DA, Kraft ML, RisStalpers $\mathrm{C}$, et al. Two frequent missense mutations in Pendred syndrome. Hum Mol Genet. 1998;7(7):1099-104.

15. Fugazzola L, Mannavola D, Cerutti N, Maghnie M, Pagella F, Bianchi P, et al. Molecular analysis of the Pendred's syndrome gene and magnetic resonance imaging studies of the inner ear are essential for the diagnosis of true pendred's syndrome. J Clin Endocrinol Metab. 2000;85(7):2469-75.

16. Fugazzola L, Cerutti L, Mannavola D, Crino A, Cassio A, Gasparoni $P$, et al. Differential diagnosis between pendred and pseudo-pendred syndromes: clinical, radiologic, and molecular studies. Ped Res. 2002;51(4):479-84.

17. López-Bigas N, Melchionda S, Cid R, Grifa A, Govea N, Zelante $L$, et al. Identification of five new mutations of PDS/SLC26A4 in Mediterranean families with hearing impairment. Hum Mutation. 2002;18(6):548-9.

18. Kopp P, Arseven OK, Sabacan L, Kotlar T, Dupuis J, Cavaliere $\mathrm{H}$, et al. Phenocopies for deafness and goiter development in a large inbred Brazilian Kindred with Pendred's Syndrome Associated with a novel mutation in the PDS Gene. J Clin Endocrinol Metab. 1999;84(1):336-41.

19. Scott DA, Wang R, Kreman TM, Andrews M, McDonald JM, Bishop JR, et al. Functional differences of the PDS gene product are associated with phenotypic variation in patients with Pendred syndrome and non-syndromic hearing loss (DFNB4). Hum Mol Genet. 2000;9(11):1709-15.

20. Yoshida A, Taniguchi S, Hisatome I, Royaux IE, Green ED, Kohn LD, et al. Pendrin Is an lodide-Specific Apical Porter Responsible for lodide Efflux from Thyroid Cells. J Clin Endocrinol Metab. 2002;87(7):3356-61.

21. Palos F, Garcia-Rendueles MER, Araujo-Vilar D, Obregon MJ, Calvo RM, Cameselle-Teijeiro J, et al. Pendred syndrome in two Galician families: insights into clinical phenotypes through cellular, genetic, and molecular studies. J Clin Endocrinol Metab. 2008;93(1):267-77.

22. Kopp P, Pesce L, Solis-S JC. Pendred syndrome and iodide transport in the thyroid. Trends Endocrinol Metabol. 2008;19: 260-8.

23. Iwasaki S, Usami S, Abe S, Isoda H, Watanabe T, Hoshino T. Long-term audiological feature in Pendred syndrome caused by PDS mutation. Arch Otolaryngol Head Neck Surg. 2001;127 6):705-8.

24. Everett LA, Morsli H, Wu DK, Green ED. Expression pattern of the mouse ortholog of the Pendred's syndrome gene (Pds) suggests a key role for pendrin in the inner ear. Proc Natl Acad Sci USA. 1999;96(17):9727-32.

25. Royaux IE, Wall SM, Karniski LP, Everett LA, Suzuki K, Knepper MA, et al. Pendrin, encoded by the Pendred syndrome gene, resides in the apical region of renal intercalated cells and mediates bicarbonate secretion. Proc Natl Acad Sci USA. 2001;98: 4221-6.

26. Wall SM, Pech V. The interaction of pendrin and the epithelial sodium channel in blood pressure regulation. Curr Opin $\mathrm{Ne}-$ phrol Hypertens. 2008;17:18-24.

\section{Correspondence to:}

Adriana Lofrano Porto

Hospital Universitário de Brasilia, Laboratório de

Farmacologia Molecular (UnB)

Caixa Postal 04473

70919-970 Brasilia DF

Email: adlofrano@unb.br 